\title{
Infidelity to True Story and Novel: Locating the Auteur in Rituparno Ghosh's Dahan
}

\author{
Akaitab Mukherjee \\ Assistant Professor, School of Social Sciences and Languages (SSL), Vellore Institute of \\ Technology (VIT), Chennai Campus, Tamil Nadu, India, akaitab.mukherjee@gmail.com, \\ ORCID id-oooo-0oo1-6410-9898
}

\begin{abstract}
Rituparno Ghosh (1961-2013), a celebrated Bengali film director who started making film in 9os, often borrows plots from literary and other cultural narratives. The essay aims to explicate Ghosh's early film Dahan (1997) which is an adaptation of distinguished Bengali novelist Suchitra Bhattacharya's novel with the same title. Bhattacharya's novel is influenced by the real incident in which a couple was harassed by four youths at Tollygunge Metro Station in Kolkata on $27^{\text {th }}$ November, 1992. The film also acknowledges that it is indebted to the true story. The essay explicates the adaptation of the two sources by the auteur. It examines the duplication of authorial concerns in this adaptation while following the narratives of two texts. Ghosh remains unfaithful to the literary text and the cultural memory of the true story to establish his authorship. As Ghosh's films portray the middle class women in patriarchal society, following Janet Staiger's reconsideration of the theory of auteur in the context of queer movement and identity politics in 1970s, the essay argues that the performance of infidelity to the literary and true story to establish authorship is auteur's "technique of the self".
\end{abstract}

Keywords: Auteur, fidelity, Dahan, Based on true story, Rituparno Ghosh

\section{Introduction}

The essay aims to explicate Rituparno Ghosh's (1961-2013) early film Dahan (1997) which is screen fictionalisation of eminent Bengali novelist Suchitra Bhattacharya's eponymous novel. Bhattacharya's novel is based on the real incident in which a couple was harassed by four youths at Tollygunge Metro Station in Kolkata on $27^{\text {th }}$ November, 1992. In the opening credit the film acknowledges that it is also influenced by this true story. The essay explicates the adaptation of the two sources by the auteur. It examines the repetition of authorial concerns in this adaptation while following the narratives of two texts. The essay unveils how Ghosh changes the narrative of the novel when he represents it on screen and establishes the stamp of his ${ }^{\mathrm{i}}$ authorship on the film adaptation. The real incident and the novel represent the victimization of middle class women which is integral part of Ghosh's authorship, but the adaptation shows his interest to exert his authorial identity.

The concept of auteur dates back to the post-war France when the qualities of film adaptations failed to appeal film critics like Francois Truffaut (2008) and others who were associated with the magazine Cahiers du Cinéma (p. 6). In his landmark essay "The Birth of a New

(c) AesthetixMS 2021. This Open Access article is published under a Creative Commons Attribution Non-Commercial 4.0 International License (http://creativecommons.org/licenses/by-nc/4.o/), which permits non-commercial re-use, distribution, and reproduction in any medium, provided the original work is properly cited. For citation use the DOI. For commercial re-use, please contact editor@rupkatha.com. 
Avant-garde: La Caméra Stylo" Alexander Astruc (2012) uses the term "camera-stylo" to illustrate that film is personal expression of the director who uses camera like a pen. This concept gave impetus to the theorizing of the concept of "auteur" (p. 182). Later it was theorized by Andew Sarris and Peter Wollen who define the concept of auteur as repetition of artistic influences, sensibility and vision in the director's oeuvre. Sarris calls this repetition of the worldview and style as the director's signature.

Janet Staiger (2003) observes that identity politics, feminist and queer movement of 1970s made the identity of the speaker important. In this situation she realized the necessity of reconsidering the definition of auteur. These movements taught that in the field of arts the need of rescuing voice of the author and when it is suppressed, the necessity to strike back becomes important. She asserts that "the author is reconceptualized as a subject having an ability to act as a conscious analyzer of the functionary of citations in historical moments" (p. 49). Moreover, when Staiger discussed about Foucauldian thesis of power, she was well aware of his idea of agency which is explained through anatomization of western sexuality in The Use of Pleasure. She argues that western sexual discourse recommends to follow morality which is nothing but following and repeating code of conduct or self-regulation. This discourse preaches that caring of one's self is "art of existence" which needs "self-knowledge". This self-knowledge, according to Foucault (2003), is acquired by "recipes, specific forms of examination, and codified exercises" (p. 58). However, Staiger found that an auteur not only secures his/her self in the space of power-struggle, but the subject takes care of his/her self by repeating the narrative style. This repetition is the "art of existence" which keeps the author alive and this practice is well appreciated in the society. Furthermore, following Judith Butler's revision of J. L Austen's speech-act theory, Staiger (2003) states that this repetition is a performative statement which creates impact on the discursive system (p. 50-51). As Ghosh's films primarily give voice to the suppressed minorities like women and queers, Staiger's interpretation of the agency of auteur seems suitable to understand Ghosh's authorship.

However, Rituparno Ghosh's authorial intentions are unequivocally reflected in his oeuvre. His films consistently portray middle class Bengali women and borrow the plots from literary sources of different languages. Apart from familiar women centric plot, his films occasionally remind Satyajit Ray's films and Rabindranath Tagore's literary world or musical genius. Indeed the women centric theme in his films, especially the struggle of female subject in patriarchal society and the portrayal of marital relationships remind Aparna Sen's films. However, Sangeeta Datta (2016) catalogues other aspects of his authorship which he repeats in his films such as: the dinner table conversation, the performer and their alteration, hidden meaning of music, film within film and suggesting an unknown expedition of the protagonist or the characters. As an auteur Ghosh repeats these narrative devices in his films which narrate different stories or present different contexts, yet the narrative of all the films seem thematically same because of this duplication. In his essay "De la Politique Des Auteurs" André Bazin (2018) illustrates this proclivity of an auteur: "whatever the scenario, he always tells the same story...let's say he has the same attitude and same moral judgments on the action and on the characters" (p. 25). Unfortunately in his interviews and articles Ghosh never unveils his ideas on auteurism.

The presence of authorship in adaptation inevitably reminds the issue of fidelity which is often considered as a parameter to evaluate an adaptation. Post-millennial discussion on adaptation theory rejects this process of evaluation. Theorists like Deborah Cartmell, Linda Hutcheon, Robert Stam and Thomas Leitch dismantle the moralistic approach of fidelity criticism and prefers to treat adaptation as intertextuality to establish the creativity of adaptation. Deborah Cartmell (2012) declares that adaptation is an "art form of democracy" (p. 1). However, David T. Johnson (2017) in 
his essay "Adaptation and Fidelity" makes us aware about a counter-narrative which consciously endorses the fidelity debate. He argues that "if fidelity studies to be rejected, but if our discourse inevitably retains the residue of fidelity, a concept that is anathema to its very identity, then what is to become of the field?" (p. 98). He recommends a comparative approach from a theoretical perspective which meticulously avoids evaluation, analysis of "adaptive system" through a comparative study and "belief study" which again tries to understand the reception of the source text. These approaches show that Johnson is treating adaptation as a postmodern art and the methods of analysis has similarity with Hutcheon's "adaptation as adaptation", overall theorists' faith in intertexualiuty and Stam's "intertextual dialogism". The difference between Johnson and others is Johnson boldly illustrates the relevance of fidelity, whereas there is "ritual slaying" (p. 95) of fidelity or a dualism in the writing of other theorists. Though the title of the essay uses the term "infidelity", the analysis of the essay does not return to the moralistic approach to prove that the film adaptation is inferior to the literary text. In this context the term "infidelity" indicates an auteur's liberty to borrow from different cultural texts and eagerness to re-narrate the story to establish his authorship. Thus the essay applies the term fidelity in the sense Johnson uses and examines the authorship of Ghosh.

The question of fidelity is inevitably reminded during analysis of a true story adaptation. Understanding the complexity of evaluation of true event adaptation, Linda Hutcheon (2006) states: "The seeming simplicity of the familiar label, 'based on a true story', is a ruse: in reality, such historical adaptations are as complex as historiography itself" (p. 18). Unlike any printed book, the true story is neither a creative work nor an organizationally sanctioned text. The adaptation of the true story and evaluation of its fidelity to the original create further problem because in most of the cases it is difficult to know the true story and as a consequence it is strenuous to judge the faithfulness to the original. Thomas Leitch (2007) in his essay "Based on True Story" unearths another dilemma of this type of adaptation. He affirms that the acknowledgement of the true story for adaptation endow authenticity in it: "The point of claiming that a film is based on a true story is not to establish truth of fidelity to the truth as a predicate of the discourse but to use the category of the true story as a privileged master text that justifies the film's claims to certain kinds of authority - ideally by placing them beyond question" (p. 286). Thus the question of fidelity becomes insignificant here.

\section{Influence of the True Story}

The director acknowledges in the opening credit of Dahan that the film is based on a true story. Like any other true story adaptation, this film also refers the "master text" and its authenticity is beyond doubt. The director goes one step further by showing newspaper clippings. Whenever the plot takes important turn, the clippings of Bengali and English newspapers are shown e.g. after the incident occurred, summon was sent to Romita's house from the court and at the end of the film when the criminals were released because of the lack of evidence. Using frequent tilt and pan he shows the newspaper reports. Ghosh takes utmost care so that the audience can read those. At the ending credit he refers the newspapers like Anandabazar Patrika, Aajkal and The Telegraph which are very popular in Kolkata and sub-urban areas of West Bengal. This acknowledgement makes the audience think that the clippings are from these newspapers. In a different way it can be said that these newspaper clippings endow credibility in the film narrative. It indicates Ghosh's eagerness to prove that his film is not taking fictional turn and he is following the acknowledged true story. Each time he shows the clippings, he reminds the audience who are experiencing the story in the darkness of auditorium that he is minutely following details of the incident. The acknowledgement of the true story adaptation and representation of circulation of the news in the print media 
compels the reader to believe that the question of fidelity is insignificant here. It seems that the true story is not a mere influence on this film, rather it has become a copy of the "master text" (p. 286).

\section{Influence of the Novel}

Along with the true story the film also concedes the influence of Bhattacharya's novel with the same title. It further admits that the film is based on both the sources. This acknowledgement dismantles the authority of true story. These two influences can create insoluble dilemma in the mind of the audience. This puzzle makes the audience believe that the film is an adaptation of the true story with reasonable fidelity. Simultaneously, the influence of the novel makes the audience think before experiencing the film that the film may borrow imaginary elements from the novel. Moreover, the blurb of the 2011 edition of the book states that the novel is inspired by the true story, but the characters and the story is fictitious. As the director uses the name of the novel, the audience thinks that it follows the novel. Conversely, the repeated use of newspaper clippings, makes the audience think that it is an adaptation of the true story. However, the influence of the novel in this film along with the true story encourages examining the narrative of film adaptation.

The narrative of the film follows the novel of Bhattacharya. Unlike Ghosh's any other adaptations, in this film he follows the text closely. The screenplay repeats the same dialogues between the characters which is quite unusual in his adaptations. As this is Ghosh's second film adaptation after Hirer Angti (1992), may be Ghosh was not confident enough to take much liberty. This aspect can be interpreted in a different way also. As Bhattacharya's novel presents the narrative of middle class women which is part of Ghosh's authorship, maybe he chooses to follow the literary narrative. Moreover, the film uses the name of the novel and repeats the names of the characters. This aspect indicates that the film follows the plot of the novel, rather than the true story.

Though the film adaptation rigorously follows the literary narrative of some parts of the novel, the adaptation deviates from the literary source several times. The film starts with the voiceover of Romita who describes her in-law's house in her letter to her elder sister. Endowing agency to the victim, the auteur veers off the literary narrative. In the letter she introduces the members of the family with her sister and also tells her how she adjusts with them. This voice-over establishes the female subjectivity of the protagonist who has been repeatedly humiliated by the patriarchal society. Giving Romita the role of the narrator, the director tries to develop affinity of the audience with the character.

The portrayal of the character of Trina shows that Ghosh's narrative again departs from the novel. She is betrothed to Ranjit who harassed Romita in the metro station. She decides not to marry him as he committed the crime. Her family persistently tries to make her understand that the newspapers are misrepresenting the incident and as Ranjit's family is rich she should marry her because of the financial security. They were also concerned about social embarrassment which may follow after the breaking off of the engagement. She repeatedly wanted to talk with Romita to know the truth. In the court when Romita lies and disapproves the accused as the same people who harassed her that night, she breaks down in tears. Indeed not only Romita and Jhinuk, Trina also faces patriarchal dominance. Most ironical incident is her mother repeatedly talks in favor of Ranjit and she tries to coax her into marry him. As a consequence she becomes a mouthpiece of the patriarchal society. 
Along with Romita and Jhinuk, delineation of the character of Trina indicates that Ghosh analyses the incident of harassment from different perspectives. He represents the viewpoint of the victim through the portrayal of Romita. Another perspective has been presented through the delineation of the character of Trina. Ghosh portrays the reaction of the criminal's friends and relatives on this incident through this characterization. He shows Trina's embarrassment when she comes to know about Ranjit's involvement in the crime and his family's complete indifference. Jhinuk and her relatives represent another perspective of the crime. This aspect highlights how Jhinuk's bravery has been treated by her relatives and colleagues of school. Thus Ghosh shows the incident through the eyes of women and from three different angels. Unfortunately these women are silenced by the hypocrisy of the patriarchal culture. Srimati Mukherjee (2016) observes that: "In Dahan, Ghosh does not hesitate to point out, however, that such masculinist manipulation and exploitation exist well beyond the frame of marriage in contemporary Bengal" (p. 39).

Ghosh further distances his narrative from the novel at the end where these three characters try to escape from the patriarchal zones. At the end of the film Romita's voiceover narrates the letter which she writes to her sister. She unveils her desire to go to Canada to enroll for a shortterm course. The repeated compromise in her in-laws forces her to take such a decision. In Ghosh's film Romita and Jhinuk do not compromise with the patriarchal system. During the voiceover Ghosh shows the interior of Palash's house, Trina in her own room and Jhinuk's return to her house alone. Though the narrative informs that the marriage of Jhinuk and her beau has been fixed, she is not able to accept him as her husband. He requested her not to identify the criminals who had harassed Romita. As one of those criminal's father is in the higher position of his company, Jhinuk's recognizing those criminals can affect his promotion. After she is humiliated in the court, he never tries to console her. Thus Ghosh tries to show that the three women in the film try to come out of the patriarchal control. But the novel ends with the description of Jhinuk and her husband Tunir's honeymoon trip and it indicates Jhinuk's complete acceptance of the patriarchal dominance. The imposition of the male desires in the novel left little room for female desires to be articulated. But Ghosh gives opportunity to these three women to establish their own space.

Primarily Ghosh's oeuvre focuses on patriarchal subjugation of female subjectivity. In his films the subdued female subjects create their own space in the patriarchal zone. Ghosh frequently borrows literary narratives where the main protagonist is a woman, for example Suchitra Bhattacharya's Dahan, Rabindranath Tagore's Chokher Bali, Agatha Christie's The Mirror Crack'd from Side to Side. His adaptation often gives more freedom to the female protagonist than the literary narrative (Chokher Bali). Sometimes his film adaptations portray the life of the marginalized women characters in male author's work (Antarmahal, The Last Lear, Satyanweshi). Hence, Dahan follows the narrative pattern of Ghosh's other films and this aspect is an evidence of Ghosh's authorial impulse. When Ghosh made Dahan, he was in early stage of his career and repeated the women centric narrative after Unishey April (1995). Bhattacharya's text serves as a ready-made plot to the feminist auteur. It can be assumed that his tendency to delineate the life of the middle class women which is integral part of his authorship, instigates him to select a women centric novel.

\section{Ghosh as an Auteur}

According to Sangeeta Datta (2016) the presentation of the performance and performer's transposition is an important aspect of Ghosh's authorship (p. 35). In her essay "Invoking Love, Death and an Elsewhere: Searching the Auteur in Rituparno Ghosh's Abohoman" Datta's analysis of performance in Ghosh's films shows that she does not use the word "performance" to indicate presentation of different types of entertainment like opera, play, concert to name a few. Rather she indicates different roles which the same character plays in Ghosh's films. This type of portrayal 
often unveils secret of the life of characters. In his film Subho Muharat the protagonist is a yesteryear film star and at the same time she is a mother who takes revenge of her child's death. In Dosar the protagonist Kaushik is happily married with Kaberi, but he often goes to trip with his mistress Mita secretively. Similarly in Abohoman the protagonist Aniket is a renowned film director and the film also unveils his relationship with the new actress Sikha. Datta's examination of this aspect of Ghosh's authorship does not include Dahan, but in this film also the female protagonists play different roles. Here Romita performs her role of middle class house wife. The voice-over of Romita at the beginning informs about her efforts to become a middle class Bengali house wife. Though she belongs to a rich family, after marriage she endeavors to adjust with the values of the middle class family of her husband. When she was harassed by those criminals, she did not find anyone except her parents by her side. Even her husband also fails to understand her condition and she becomes subject of domestic violence. When she receives summon from the court, she is humiliated by her father-in-law. She is forced by her husband not to tell the truth in the court. She fails to compromise with the hypocrisy of in-laws and decides to leave her house. Thus in the film she performs the role of a perfect house wife, but at the end she discontinues this performance. Jhinuk and Trina perform the role of beloved of their beaus and they seem to be perfect in their roles. Jhinuk is a school teacher and daughter of a professor. After the incident, Jhinuk's beau stands by her when she tries to help Romita. But when he becomes concerned for his promotion, he changes his stance and requests Jhinuk not to recognize the criminals in the court. But rebellious Jhinuk remains unable to accept that. At the end of the film it is informed that both of them are getting married, but the conversation between Jhinuk and her grand-mother shows that Jhinuk is not able to forgive him. It seems that her parents force her to marry. Throughout the film Jhinuk performs the role of an ardent lover, but she fails to play the same role as the situation alters. On the other hand, Jhinuk's beau who performed the role of a caring lover at the beginning, later he transforms into a selfish, insensitive and egoist man who advocates patriarchy. However, the film does not narrate the relationship of Trina and Ranjit in much detail. The narrative of film shows that her beau is from a reputed family. But another facet of this character is unveiled when he commits the crime with his friends. Moreover, Romita's father-in-law at the beginning of the film appreciates the bravery of Jhinuk. Later when she calls Romita to ask about her health, her fatherin-law behaves in a rude way. Apparently he poses like an educated and well-mannered person, but the film shows that he is a patriarch who likes to suppress the voice of the women. In this film these characters make different performances in different situation. The performance of the women characters does not disclose any secret in their life, whereas the close examination of the performance of the male characters unearths hidden aspects of their character. Considering this type of sanctimony of some characters in Ghosh's films, Rohit K. Dasgupta and Tanmayee Banerjee (2016) remarks that, “...Ghosh has constantly attempted to expose the sham progressiveness of a society that has more often than not been insensitive to human emotions and desires" (p. 35).

Sangeeta Datta (2016) also states that Ghosh's films indicate an “elsewhere” (p. 44). Through this word Datta indicates multiple aspects, yet she primarily focuses on Ghosh's fascination with the idea of death. She points out the obsession of the director to portray death in films like Dosor, The Last Lear and Abohoman and Sob Charitro Kalponik. Along with these films she gives example of Chokher Bali where the female protagonist Binodini suddenly cancels her marriage with Bihari and leaves for some unknown destination. Datta also cites Ghosh's another film Antarmahal where the landlord's second wife Jashomati commits suicide. In later two films Binodini's run away and Jashomati's suicide can be interpreted as quest for their own space and escape from patriarchal dominance. In these films Ghosh's women protagonists succeed in establishing their own space which is beyond the reach of the patriarchal suppression. Binodini and Jashomati find "elsewhere" 
when they dismantle patriarchal domination and create their own space. This quest for "elsewhere" which is integral part of Ghosh's authorship can be found in Dahan also. At the end of Dahan, three women characters goes to an unknown journey as they are unable to accept the patriarchal control. Srimati Mukherjee justifiably opines (2016): "His directorial intent is to take us inside the Bengali household and markedly masculinist matrimonial structure to show how such 'publicizing' of 'private injuries'...is suppressed" (p. 40). However, Romita in her letter to her elder sister states that she wishes to go to Canada to enroll for a course which will give her a break from the present situation and she is tired of her compromise in her daily life. Her distance from her husband also influences her to take this decision. At the end of the film, audience is informed that Jhinuk is getting married with his beau Tunir. But it seems that the marriage is forced by her parents, rather than her own wish. She planned to introduce him with her grand-mother, but even after waiting for a long time, he does not arrive. Finally she decides to return to her house. This distance between them indicates the mutual disinterest in marriage and in spite of her strong antipathy Jhinuk cannot cancel the marriage. Unlike Bhattacharya's novel, Ghosh does not end the film with Jhinuk's honeymoon. It seems that there is still a possibility of canceling the marriage. When Romita was reading out the letter written to her elder sister, the film shows Trina in her study. The film does not give any hint of her marriage with the criminal Ranjit and the audience can assume that the director gives her liberty to confine herself within a room of her own. Thus Ghosh in this film gives liberty to these three women characters to choose their own path. Apart from these three main characters, the grandmother of Jhinuk who is always a moral support for her, chooses to spend the rest of her life in an old age home. Though Jhinuk's father is willing to take care of her, she decides to live on her own terms. In case of Romita, this expedition is indicated, but in the case of other two characters, it is vague. However, Ghosh's fascination of portraying death of the protagonist or the idea of death is absent in this film. Here he presents these characters' journey to an unknown "elsewhere" which is literary no man's land and devoid of the idea of death.

Ghosh's films show his fascination for half dim room where the characters interact with each other. His oeuvre repeats this technique of the cinematography repeatedly. This aspect of his authorship is present in Dahan also. After showing Romita's in-laws and their congested locality, Ghosh shocks his audience with the first scene of darkness where Romita is molested. After that there are multiple scenes in this film where darkness prevails. There are large number of scenes in the house of Romita, Jhinuk and Trina which are shot in half dim room. This darkness can be interpreted as a symbol of patriarchy which covers the home of Romita, Jhinuk and Trina. It repeatedly tries to control them. Obsession with this technique of cinematography in his films makes us think that darkness of patriarchy has been represented in his oeuvre and his films are indeed critique of this patriarchal dominance. However, this interpretation is reinforced when at the end of the film Ghosh shows empty bedroom of Romita and Palash which is full of daylight. Ghosh shows the empty bedroom where Romita was once raped by her husband and in the background the voiceover of Romita informs the audience that she is going to Canada. The room looks mysterious with the abundance of sunrays and to convince the audience that this is Romita's bed room the director shows their dresses are handing in that room. However, this scene is interrupted by the scene of Trina's studying and later the camera comes out of the room to show the congested locality when Romita's voiceover describes the loneliness of people and the scene of Jhinuk's leaving old age home all alone follows. Camera's travel inside Romita's illuminated bedroom visually prepares the audience to think that darkness of the patriarchal zone vanishes as these three women are liberated. 
As this is one of the early films of Ghosh, other aspects of authorship like film within film, songs with interior meaning, dinner table conversation are not reflected in it. Along with repetition of thematic styles, an auteur also repeats his influences in his/her oeuvre. The influence of Satyajit Ray and Rabindranath Tagore are integral part of his authorship. Either he recreates some scenes of Ray's films in his movies or borrows Tagore's stories from novel or play. He often uses Tagore's songs in his films which emphasize the emotion crated by visuals. Rohit K. Dasgupta, Sangeeta Datta and Kaustav Bakshi (2016) assert that: "Ghosh not only modeled his story telling technique on Ray's template, but also followed his diligent research and eye for detail" (p. 11). The story of molestation and its trial reminds Ray's city trilogy, namely Pratidwandhi (1970), Seemabaddha (1971) and Jana Aranya (1975). These films show how troubled middle class families lose their way when they encounter relentless corruption and leaving human values they struggle to survive in the city which is dominated by degenerated bourgeois class. As an auteur Ghosh sees this degeneration through the eyes of women characters and finds the hypocrisy of the middle class families. It seems Ghosh reminds in this film that the corruption and domination of powerful people which we have encountered in Ray's films, continues still now. From this perspective, there is an echo of Ray's skepticism towards city dwellers which is prevalent in his films of 1970s. Those who are aware of Ghosh's narrative style and Ray's oeuvre, they will easily locate the similarity of tone in Ghosh's Dahan and Ray's city trilogy. Similarly Tagore's influence exists in this film, but not as a part of the main narrative. In one scene of the film where Jhinuk's father lies on the bed and her mother is combing her hair inside the bedroom cum study and discussing over their son's future, two songs of Tagore are heard as a non-diegetic narrative. This setting indicates a typical middle class Bengali family which treats Tagore as their cultural icon and it is an evidence of the director's expression of artistic influence. Thus Ghosh uses Tagore's song to create a situation.

\section{Auteur versus Novel and True Story}

The analysis of the narrative of Dahan shows that women centric theme is auteur's citation and to illustrate this citation he uses different narrative devices like performance of characters, journey to an "elsewhere", his own cinematographic style, borrowing Tagore's song and following the theme of Ray's city trilogy. Ghosh chooses the theme of oppression of women in a patriarchal society and through the narrative of oppression the voice of auteur is heard. His narrative as a site of power struggle shows the resistance of women protagonists when they are oppressed and then they are liberated. Following Staiger (2003) it can be said that the mentioned narrative devices are "recipes, specific forms of examination, and codified exercises" (p. 58) which Ghosh uses in Dahan. It is obvious that some narrative devices are absent in this film, but that does not rise question on Ghosh's authorship. A person who is familiar with the oeuvre of Ghosh, can easily understand that Dahan consists Ghosh's authorial signature. Like his previous film Unishe April (1995), in this film Ghosh repeats a women centric theme and it continues in the next film Bariwali (1999) and later films. Not merely these films duplicate the same theme, but they follow the same narrative style. Thus one can locate the director's tendency of taking care of his self in his oeuvre and this exercise proves his existence. This fashioning of the self has been executed through repeated analysis of women's space in patriarchal society. This tendency of the auteur to care for one's self, makes Staiger (2003) to state that: "Authorship is also a technique of the self, creating and recreating the individual as an acting subject within history" (p. 50). This technique of Ghosh's self becomes unambiguous when his authorship is examined. After Unishe April, he recreates his author's self in Dahan and this practice continues. The narrative devices like film within film, song with interior meaning and dinner table conversation are added in his later films as a process of recreating his authorial identity. Moreover, this type of care of the self through repetitive narrative style has been 
presented in a socio-cultural space which celebrated the authorship of Satyajit Ray, Mrinal Sen, Ritwik Ghatak and others and believes in the author-function. Hence his narrative strategy has been considered as a performative statement. The well-known statement that Ghosh's films "brought the Bengali middle class back to the audience" (Chaudhury, 2016, p. 104) is often quoted to describe the reception of his films. It reminds that his performative statement is well appreciated among the audience.

However, when Ghosh makes performative statement, he spontaneously makes additions and exclusions. But the adaptation shows that he makes the issue of oppression of women more powerful. The blurb of the 2011 edition of the novel states that the aim of the author was to unveil the actual condition of women empowerment during 1998 when the novel was first printed and analysis of values of contemporary society. The title of the novel literary means burning and the subject of the novel indicates that the novelist portrays suffering of women characters in a patriarchal society. Following Astruc (2012) we can say that like the literary author Ghosh re-writes the victimization of women using camera and makes alteration in the narrative to establish his authorship. Yet a sensitive audience can easily realize that the female protagonists are in a way burning through molestation, subjugation and domestic violence in Ghosh's adaptation. As Ghosh widens the horizon of the novel by creating new characters in the adaptation, he discloses the irony of women empowerment like Bhattacharya in his adaptation and his tone becomes more poignant. Moreover, this approach adds multiple intertextual layers in the adaptation, ranging from literary narrative, true story and Ghosh's authorship. From the perspective of David T. Johnson's fidelity/belief studies we find here the influence of the literary text and the cultural memory of the true story. This evaluation helps to understand the literary author's belief and Ghosh's own belief. The infidelity of the adaptation to the literary text indicates that Ghosh's approach is critical about author's belief. In spite of being unfaithful to the literary narrative and addition of multiple intertextual layers, Ghosh tries to maintain the "equivalence in meaning" in the film adaptation which Bazin (2012) recommends in his landmark essay "Adaptation, or the Cinema as Digest" (p. 58).

Apart from the novel, the influence of the true story creates dilemma. Because it also acknowledges that it is indebted to the novel and these two acknowledgements confuse the audience. Using newspaper clips the director tries to associate the film narrative with the master narrative or true story which is at present buried in the newspaper reports (Leitch, 2007, p. 302). Thus it tries to create a tone of documentary, yet all those efforts go to vain when the adaptation follows the narrative of the novel. Usually an adaptation of the true story is placed beyond question as the adaptation is endowed with authority of the representing truth, but Dahan loses this status because of its association with novel. Thus the element of truth of the true incident exists in this adaptation merely as an interext, and the adaptation fails to achieve the "transcendental authority" (Leitch, 2007, p. 289) of true story adaptation. Indeed the similarity of true story with Ghosh's tendency to frame women centric narrative assists him to perform his authorship. While Ghosh primarily follows the novel, he refers newspaper clippings to sensitize the audience. A feminist auteur's reference to newspaper makes his views on women's security and law more powerful. These newspaper clippings function as evidences of the argument of the auteur. Thus Ghosh's narrative makes the audience travel through the allies of the fictional world, but he also tries to give the shock of reality. Bhattacharya's novel frames the fictional world, whereas the reference of the true story brings the audience back to reality. When Shelley Cobb (2012) evaluates film adaptations of auteur in her essay "Film Authorship and Adaptation", she argues that those adaptations seem like the original work of the director because of the repetition of authorship. As a consequence 
adaptation of the auteur is often treated as a "production" or expression of the auteur's creativity, rather than a mechanical reproduction of literary text on screen (p. 108). Ghosh's expression of authorship through the presentation of muffled voices of women, liberating them and the repetition of his narrative style easily persuades to think that the film is Ghosh's original work, not an adaptation. Establishing Ghosh's "artistic paternity" (Cobb, 2012, p. 108) through authorship makes the acknowledgement of the two sources insignificant. It seems that this visual narrative is a "production" of Ghosh, rather than adaptation of Bhattacharya's fiction or the true story. Cobb argues that "This transfer of ownership, gained by the recoding of adaptation into a productive activity, becomes a signifier of authority and originality-two signs central to the image of the auteur" (p. 108). As the adaptation seems like expression of Ghosh's creative impulse, the main characteristics of auteur i.e. authority and originality are secured.

\section{Conclusion}

While arguing on analyzing belief from different perspectives to scrutinize the infidelity to the source, David T. Johnson (2017) urges to investigate the influence of these beliefs on socio-cultural fabric. An auteur's belief is reflected in his/her adaptation and it obviously creates an impact on society. Stainer's observes "The citation affirms and produces the norm" (p. 51). Repeated citation of authorship through the narrative of women's suppression and at the end their liberation in Ghosh's films gives a message to the society that women will come out of the oppression of the patriarchy. Considering this subjection of women Beauvoir (1997) argued "One is not born, but rather becomes a woman". This rebellious auteur resists the process of "becoming" woman of his women protagonists, performs infidelity to the literary texts to liberate women characters and secures his authorship. He tries to create new significance of being born as a woman though this type of liberation of women. Wimal Dissanayke (2016) observes that: "Ghosh's intention, as I understand it, was to construct a cinema of possibilities that was motivated by a transgressive impulse. He was interested in fashioning, through his cinematic style, a free world unfettered by self-annihilating conventions" (p. 58). In Dahan Ghosh's inevitable infidelity to literary and another cultural text is "technique of the self" which tries to secure his belief on freedom. Yet he remains faithful to his authorial identity which is nucleus of authorial adaptation according to James Naremore (p. 8).

\section{Note}

\footnotetext{
i The paper consciously uses the pronoun "he". Kaustav Bakshi and Parjanya Sen (2016) in their essay "A room of hir own: the queer Aesthetics of Rituparno Ghosh" and Aniruddha Dutta (2016) in "Beyond the Binary: (Trans)gender Narratives and Class Distinction in Rituparno Ghosh's Later Films" use the gender-neutral pronoun "hir". These two essays are published in the edited volume Rituparno Ghosh: Cinema, Gender and Art along with ten other essays which use the male gender indicating pronoun "he". In her book Women and Resistance in Contemporary Bengali Cinema: A Freedom Incomplete Stimati Mukherjee (2016) uses the pronoun "he" in her essays on Ghosh. It indicates that the authors of the large number of essays felt that addressing Ghosh as "he" does not make their interpretation of Ghosh's films ambiguous. This essay follows this strategy of analysis. As this essay primarily focuses on the narratological aspect in Dahan and does not refer the director's queer aesthetics, it address Ghosh as "he".
} 


\section{References}

Astruc, Alexandre. (2012). The Birth of a New Avant-Garde: La Caméra Stylo. In Timothy Corrigan (Ed.), Film and Literature: An Introduction and Reader (pp. 181-184). New York: Routledge.

Bakshi, Kaustav, \& Sen, Parjanya. (2016). A Room of Hir Own: The Queer Aesthetics of Rituparno Ghosh. In Sangeeta Datta \& Kaustav Bakshi \& Rohit K. Dasgupta (Eds.), Rituparno Ghosh: Cinema, Gender and Art (pp. 204-225). New York: Routledge.

Bazin, André. (2012). Adaptation, or the Cinema as Digest. In Timothy Corrigan (Ed.), Film and Literature: An Introduction and Reader (pp. 57-64). New York: Routledge.

Bazin, André. (2008). De la Politique des Auteurs/ In Barry Keith Grant (Ed.), Auteurs and Authorship: A Film Reader (pp. 19-28). United Kingdom: Blackwell Publishing.

Beauvoir, Simone de. (1997). The Second Sex (Howard Madison Parseley. Trans.). United Kingdom: Vintage. (Original work published 1949)

Bhattacharya, Suchitra. (2011). Dahan. Kolkata: Ananda Publishers.

Cartmell, Deborah. (2012). 100+ Years of Adaptations, or, Adaptation as Art form of Democracy. In Deborah Cartmell (Ed.), A Companion to Literature, Film, and Adaptation (pp. 1-14). United Kingdom: WileyBlackwell.

Chowdhury, Sayandeb. (2016). The Endangered City in Rituparno Ghosh's Early Cinema of Confinement. In Sangeeta Datta \& Kaustav Bakshi \& Rohit K. Dasgupta (Eds.), Rituparno Ghosh: Cinema, Gender and Art (pp. 104-122). New York: Routledge.

Cobb, Shelley. (2012). Film Authorship and Adaptation. In Deborah Cartmell (Ed.), A Companion to Literature, Film, and Adaptation (pp. 105-121). United Kingdom: Wiley Blackwell.

Dasgupta, Rohit K., Datta, Sangeeta, \& Bakshi, Kaustav. The World of Rituparno Ghosh: An Introduction. In Sangeeta Datta \& Kaustav Bakshi \& Rohit K. Dasgupta (Eds.), Rituparno Ghosh: Cinema, Gender and Art (pp. 1-26). New York: Routledge.

Dasgupta, Rohit K., \& Banerjee, Tanmoayee B. (2016). Exploitation, Victimhood and Gendered Performance on Rituparno Ghosh's Bariwali. Film Quarterly, 69(4), 35-46. https://doi.org/10.1525/fq.2016.69.4.35

Datta, Sangeeta. (2016). Invoking Love, Death and Elsewhere: Searching the Auteur in Rituparno Ghosh's Abohoman. In Sangeeta Datta \& Kaustav Bakshi \& Rohit K. Dasgupta (Eds.), Rituparno Ghosh: Cinema, Gender and Art (pp. 29-48). New York: Routledge.

Dissanayake, Wimal. (2016). Rituparno Ghosh and the Pursuit of Freedom. In Sangeeta Datta \& Kaustav Bakshi \& Rohit K. Dasgupta (Eds.), Rituparno Ghosh: Cinema, Gender and Art (pp. 49-62). New York: Routledge.

Dutta, Aniruddha. (2016). Beyond the Binary: (Trans)gender Narratives and class distinction in Rituparno Ghosh's Later Films. In Sangeeta Datta \& Kaustav Bakshi \& Rohit K. Dasgupta (Eds.), Rituparno Ghosh: Cinema, Gender and Art (pp. 170-189). New York: Routledge.

Ghosh, Rituparno. (Director). (1997). Dahan (Film). G P Films Pvt. Ltd.

Hutcheon, Linda. (2006). A Theory of Adaptation. New York: Routledge.

Johnson, David T. (2017). Adaptation and Fidelity. In Thomas Leitch, The Oxford Handbook of Adaptation Studies (pp. 87-100). New York: Oxford University Press

Leitch, Thomas. (2007). Film Adaptations and Its Discontents: From Gone with the Wind to the Passion of the Christ. United States: John Hopkins University Press. 
Mukherjee, Srimati. (2016). Women and Resistance in Contemporary Bengali Cinema: A Freedom Incomplete. New York: Routledge.

Naremore, James. (2001). Introduction: Film and the Reign of Adaptation. In James Naremore (Ed.), Film Adaptation (pp. 1-18). London: Rutgers.

Staiger, Janet. (2003). Authorship Approaches. In David A. Gerstner \& Janet Staiger (Eds.), Authorship and Film (pp. 27-6o). New York: Routledge.

Truffaut, Francois. (2008). A Certain Tendency of the French Cinema. In Barry Keith Grant (Ed.), Auteurs and Authorship: A Film Reader (pp. 9-18). United Kingdom: Blackwell Publishing.

Akaitab Mukherjee is Assistant Professor of English in School of Social Sciences and Languages (SSL), Vellore Institute of Technology (VIT), Chennai, India. He has completed graduation in English Literature from Krishnagar Government College (affiliated to University of Kalyani) and post-graduation in the same subject from Pondicherry University. He has completed his doctoral research in the area of film adaptation from Indian Institute of Technology (Indian School of Mines), Dhanbad. He can be contacted at akaitab.mukherjee@gmail.com 